\title{
Production of Lactic Acid from Empty Fruit Bunch of Palm Oil Using Catalyst of Barium Hydroxide
}

\author{
Apsari Puspita Aini, Hyung Woo Lee, Johnner Parningotan Sitompul, and Carolus Borromeus Rasrendra* \\ Department of Chemical Engineering, Faculty of Industrial Technology, Institute of Technology Bandung, 40132 Bandung, Indonesia
}

\begin{abstract}
Lactic Acid as a platform chemical has broad application in various industries, especially in the production of Poly Lactic Acid (PLA) for biodegradable plastic. Empty fruit bunch (EFB), abundant by product from palm oil mill industry, is one of potential feedstock to be used in the production of lactic acid from lignocellulose biomass. EFB contains high cellulose and hemicellulose about $37-59.7 \% \mathrm{w} / \mathrm{w}$ and $16-28 \% \mathrm{w} / \mathrm{w}$, respectively. The aim of this paper is to study the effects of the operating conditions, such as temperature, reaction time, biomass loading, and catalyst concentration on the yield of lactic acid using barium hydroxide as alkaline catalyst. EFB pretreatment with steam explosion was applied to remove lignin content. The results showed that pretreatment reduced the lignin content from $22.66 \%$ to $9.69 \% \mathrm{w} / \mathrm{w}$. Meanwhile, hemicellulose and cellulose increased from $14.40 \%$ to $16.40 \% \mathrm{w} / \mathrm{w}$ and $29.37 \%$ to $63.57 \% \mathrm{w} / \mathrm{w}$, respectively. The highest yield of lactic acid was $21.57 \% \mathrm{C}$-mol, achieved by using $0.25 \mathrm{M} \mathrm{Ba}(\mathrm{OH})_{2}$ as the catalyst, with $5 \% \mathrm{w} / \mathrm{v}$ biomass loading, temperature $240^{\circ} \mathrm{C}$, during $4 \mathrm{~h}$ reaction times. The yield was approximately equal to yield of lactic acid $(\sim 20 \%)$ compared with $\mathrm{Pb}^{2+}$ as the catalyst for EFB conversion although the later catalyst produced fewer by products during conversion.
\end{abstract}

\section{Introduction}

Palm oil is one of the plantation crops, the source of non-oil foreign exchange for Indonesia. Other than the production of palm oil, margarine, and the cosmetics industry, the palm oil industry also produces liquid and solid waste. About 20 percent of oil palm empty fruit bunch (EFB) is produced from the processing of fresh fruit bunch [1]. The oil palm empty fruit bunch is one of lignocellulosic raw material. Lignocellulose is a major part of the plant cell wall, which consists of cellulose, hemicellulose, and lignin, and comprise a small amount of pectin, protein, extractive, and ash. Cellulose, hemicellulose and lignin content in EFB are about 37$59.7 \%, 16-28 \%$, and $10-32 \%$ [2]-[5]. Limited utilization of EFB for fertilizer on oil palm plantation areas has forced many researchers to use EFB as raw material for various applications, one of which is lactic acid, the raw material for the production of Poly Lactic Acid (PLA).

Lactic acid is one of the chemical platforms that can be applied in chemical industry, food, the pharmaceutical industries, and cosmetics. Lactic acid has a strong market growth. It is included in the top 30 basic chemicals with significant market growth potential in the PLA and solvent industries. Global lactic acid is estimated to grow from 714.2 kilotons in 2013 to 1960.1 kilotons by 2020 [6]. Utilization of lactic acid as a primary material for PLA synthesis to produce biodegradable plastics is expected to be a replacement for plastic produced from petroleum. Due to the increase of awareness among consumers and plastic producers about the environment, PLA's market growth as biodegradable plastic will increase. It also means that the demand for lactic acid, a PLA raw material will increase as well.

Various substrates such as triose, hexose, cellulose or lignocellulose can be used as feedstocks in the production of lactic acid [7]-[12]. The production of lactic acid can be carried out by chemical synthesis, fermentation, and catalytic conversion pathways. The production of lactic acid with chemical synthesis pathways has some limitations because the raw materials depend on the by-products of other processes, Lacto nitrile, and the inability to produce L-lactic acid stereoisomers [8], [13]. The production of lactic acid with fermentation process was more advantageous than with chemical synthesis. This is because it can produce the desired stereoisomer, L-(+)-lactic acid or D-(-)-lactic acid [8]. Although more than $90 \%$ of lactic acid production is produced from fermentation, this method has some disadvantages such as reactor control, temperature, $\mathrm{pH}$, and microorganism control. Otherwise, it takes a longer reaction time to produce lactic acid. The production of lactic acid by catalytic conversion process is expected to improve the disadvantages in chemical synthesis and fermentation process.

\footnotetext{
Corresponding author: cbr@che.itb.ac.id
} 
Nowadays, the high percentage of lactic acid yield can be achieved with triose as raw material, such as dihydroxyacetone, and glyceraldehyde [7], [9], [14], [15]. It is because triose is a short chain of sugar, which leads to a shorter reaction pathway of lactic acid production when it is compared with other raw materials. The use of other raw materials such as cellulose and lignocellulose has not been able to produce a very high yield of lactic acid than those obtained with triose.

Research conducted by Wang et al., 2013, Sitompul et al. 2014, and Chin et al., 2016, suggested that $\mathrm{Pb}^{2+}$ is selective catalyst for the reaction of lactic acid production. The yield of lactic acid from the cellulose-ball mill was $68 \%$ using $\mathrm{Pb}^{2+}$ as a catalyst with the addition of $\mathrm{N}_{2} 2 \mathrm{MPa}$ [11]. Meanwhile, the raw material of EFB the yield of lactic acid was $8.33 \% \mathrm{~m} / \mathrm{m}$ and $6.21 \% \mathrm{~m} / \mathrm{m}$ using $\mathrm{AlCl}_{3}$ [12].

Esposito and Antonietti (2013) conducted research on the production of lactic acid with glucose as raw material. The yield of lactic acid with the temperature of $220^{\circ} \mathrm{C}$ and $12 \mathrm{~h}$ reaction time, using $0.05 \mathrm{M} \mathrm{Ca}(\mathrm{OH})_{2}$, $\mathrm{Sr}(\mathrm{OH})_{2}$, and $\mathrm{Ba}(\mathrm{OH})_{2}$ were $49 \%, 50 \%$, and $53 \%$, respectively. Fewer product yields such as formic acid (4.4-5.9\%) and acetic acid (5-7.6\%) in their study showed that $\mathrm{Ca}(\mathrm{OH})_{2}, \mathrm{Sr}(\mathrm{OH})_{2}$, and $\mathrm{Ba}(\mathrm{OH})_{2}$ is a highly selective catalyst in the formation of lactic acid. In addition to producing a good yield, this catalyst is also safer and less environmentally benign compared to other catalysts. Furthermore, Chin et al. (2016) suggested that the yield of lactic acid achieved for EFB as raw materials without pre-treatment and with the pretreatment using ball mill are $24.8 \% \mathrm{~mol}$ and $46.5 \%$ mol, respectively. In addition to shrinking size, ball mill can also reduce the crystallinity of EFB. This was resulted in the process of hydrolysis of EFB into a sugar monomer that is easier than EFB without ball mill treatment. So that, the higher yield of lactic acid can be achieved. Due to the high level of $\mathrm{Pb}$ toxicity, alternative catalysts may be required to replace $\mathrm{Pb}$.

This study was expected to improve the conversion process of EFB into lactic acid, to overcome the obstacles, such as biomass structure recalcitrance that arise in previous studies. The objectives of this study were to study the effect of alkaline catalysts utilization such as $\mathrm{NaOH}, \mathrm{Ca}(\mathrm{OH})_{2}$ and $\mathrm{Ba}(\mathrm{OH})_{2}$, conversion of pre-treated EFB to lactic acid, and to evaluate the effect of several operating parameters on lactic acid obtained. In order to reduce existing lignin content, EFB needs to be treated as early as possible using steam explosion [16]-[19].

\section{Materials and Methods}

\subsection{Materials}

The Oil Palm Empty Fruit Bunch (EFB) was collected from Riau Province. The microcrystalline cellulose was purchased from Kuraray Co., Ltd. The chemicals used in this experiment were D-(+)-glucose (99\%, Merck), D-(+)-xylose (99\%, Merck), lactic acid (90\%, Merck), Formic acid (98\%, Merck), Acetic Acid (99\%, Merck), and Levulinic Acid (Merck).
The EFB was rinsed with water to remove other contaminants, then dried using sunlight. Size reduction of EFB carried out using scissor and disc mill. It was sieved into sizes $60-80$ mesh and dried by oven at a temperature of $100^{\circ} \mathrm{C}$ until achieved a constant weight.

To know the content of cellulose, hemicellulose, and lignin, the EFB was characterized by using NREL (National Renewable Energy Laboratory) method. The determination of lignin content includes acid insoluble lignin (AIL) and acid soluble lignin (ASL). The content of cellulose and hemicellulose were known by analyzing the filtrate of hydrolysis using HPLC (High Performance Liquid Chromatography). The analysis began with the preparation of several sugar standard calibration solutions, sugar standard calibration verification solutions, and sample solutions. Standard calibration solutions were prepared from D-(+)-glucose and D-(+)xylose.

\subsection{The EFB pretreatment}

Steam explosion method was used to reduce the lignin content in EFB. 50 grams of EFB 60 mesh and $\mathrm{NaOH} 0.5 \mathrm{M}$ were input into the reactor, with $500 \mathrm{ml}$ reaction volumes. The operating conditions of pretreatment was $180^{\circ} \mathrm{C}, \pm 12$ bar and $1 \mathrm{~h}$ of reaction time. After pretreatment, the EFB fiber was washed in order to neutralised the $\mathrm{pH}$, and was dried in $100^{\circ} \mathrm{C}$ until it achieved a constant weight. To determine the cellulose, hemicellulose, and lignin content after pretreatment, the EFB was characterized using NREL (National Renewable Energy Laboratory) method.

\subsection{Conversion of EFB to lactic acid}

Pre-treated EFB and cellulose microcrystalline were used as the raw material in this experiment. The conversion of EFB to lactic acid was carried out by hydrothermal process using high-pressure stainless steel autoclave with a stirrer to homogenize the raw material and the catalyst during the reaction.

This experiment consist of the variation of alkaline catalyst $\left(\mathrm{Ba}(\mathrm{OH})_{2}, \mathrm{Ca}(\mathrm{OH})_{2}, \mathrm{NaOH}\right)$, temperature (160$\left.240^{\circ} \mathrm{C}\right)$, reaction time $(1-6 \mathrm{~h})$, catalyst concentration $(0.05-0.25 \mathrm{M})$ and biomass loading $(2.5-7.5 \% \mathrm{w} / \mathrm{v})$. The reaction volume of each run was $80 \mathrm{ml}$. The highest yield was achieved from variation of the catalyst then be used to examine the effect of some parameter above.

\subsection{Analytical method}

Lactic acid was the product of hydrothermal process and other byproducts, such as formic acid, acetic acid, and levulinic acid were analysed by HPLC (High Performance Liquid Chromatography), equipped with an RI detector and Phenomenex Rezex ROA-Organic Acid $\mathrm{H}^{+}$column $(300 \times 7.8 \mathrm{~mm})$ and $0.005 \mathrm{M} \mathrm{H}_{2} \mathrm{SO}_{4}$ as the mobile phase. HPLC was operated at $60^{\circ} \mathrm{C}$, with flow rate $0.6 \mathrm{ml} / \mathrm{min}$. To determine the concentration of the product, a standard curve was necessary. The concentration of the product was calculated on the basis of C-mol product compared to C-mol of the raw material.

\section{Result and Discussion}




\subsection{Characterization and pretreatment of EFB}

The pre-treatment of EFB was aimed to remove the lignin content. Various pre-treatment on lignocellulose biomass as follows: physical, chemical, biological, and physicochemical treatment, have been done by previous research. Physical treatment involves mechanical comminution, pyrolysis, and radiation with high energy. Chemical treatment is treatment using acid, alkaline, oxidative delignification, ozonolysis, and organosolv, ionic liquids pretreatment. In biological treatment, microorganisms (several white-rot fungi) have been examined on lignocellulosic biomass and showed the high yield of delignification. Physico-chemical pretreatment involves steam explosion, ammonia fiber explosion, $\mathrm{CO}_{2}$ explosion, liquid hot water, wet oxidation, etc [16], [17], [19], [20].

Considering the advantages and disadvantages of each process, steam explosion pretreatment with alkaline was the most appropriate process to apply in this experimental. The results of an experiment conducted by Jeon et al. (2014) showed that enzymatic digestibility of EFB using Changhae Ethanol Multiexplosion (CHEMEX), 83.6\%, was higher than the other pretreatment processes. The high yield of enzymatic digestibility is required for bioethanol fermentation process on a further step. The amorphous structure of EFB after CHEMEX treatment causes the enzyme to easily access the cellulose and hemicellulose chains, convert them into glucose and was used in bioethanol fermentation. In addition to being easily accessible by enzymes, amorphous structure of EFB will also greatly affect chemical conversion using a catalyst.

Table 1. The chemical composition of Oil Palm Empty Fruit Bunch

\begin{tabular}{|c|c|c|}
\hline Composition & $\begin{array}{c}\text { Before } \\
\text { pretreatment } \\
(\% \mathbf{\%} / \mathbf{w})\end{array}$ & $\begin{array}{c}\text { After } \\
\text { pretreatment } \\
(\mathbf{\%} / \mathbf{w})\end{array}$ \\
\hline Cellulose & 29.37 & 63.57 \\
\hline Hemicellulose & 14.40 & 17.30 \\
\hline Lignin & 22.66 & 9.69 \\
\hline
\end{tabular}

The characterization of EFB by NREL method showed that EFB pretreatment reduced the lignin content from $22.66 \%$ to $9.69 \% \mathrm{w} / \mathrm{w}$. Meanwhile, hemicellulose and cellulose increased from $14.40 \%$ to $16.40 \% \mathrm{w} / \mathrm{w}$ and $29.37 \%$ to $63.57 \% \mathrm{w} / \mathrm{w}$, respectively. The reduced lignin content causes the catalyst more easily accesses cellulose and hemicellulose chains to be converted to lactic acid.

\subsection{Catalytic Conversion of EFB into Lactic Acid}

The yield of lactic acid as main product from EFB catalytic conversion was determined by using HPLC analysis with a retention time of 30 minutes. The organic acid that was showed in HPLC chromatogram consists of lactic acid, formic acid, acetic acid, levulinic acid, and other byproducts. The 5-hydroxymethyl furfural (5HMF), furfural, or other intermediate products have not been identified. It was seen from the brown color of the liquid product of the reaction [21].
The alkaline catalysts used in the production of lactic acid were $\mathrm{NaOH}, \mathrm{Ba}(\mathrm{OH})_{2}$, and $\mathrm{Ca}(\mathrm{OH})_{2}$. It was found that $\mathrm{Ba}(\mathrm{OH})_{2}$ is the best catalyst to produced lactic acid. The highest yield of lactic acid using $\mathrm{Ba}(\mathrm{OH})_{2}$ at $200^{\circ} \mathrm{C}$ was $7.40 \% \mathrm{C}$-mol. The highest yield of lactic acid using $\mathrm{Ba}(\mathrm{OH})_{2}$ in this experiment was in accordance with previous research conducted by Esposito and Antonietti (2013) and Li (2014).

$\mathrm{Ba}(\mathrm{OH})_{2}$ was able to produce a high yield of lactic acid due to the size of its ionic radius, which can catalyze a 1.2-hydride shift. The size of ionic radius for metal ions are $\mathrm{rBa}^{2+}: 0.136 \mathrm{~nm} ; \mathrm{rCa}^{2+}: 0.100 \mathrm{~nm}$; and $\mathrm{rNa}$ : $0.102 \mathrm{~nm}$. The larger ionic radius, the better catalytic effect occurs. It also occurs in the production of lactic acid from glycerine by using $\mathrm{Mg}(\mathrm{OH})_{2}$ and $\mathrm{Ca}(\mathrm{OH})_{2}$ catalysts, where the yield of lactic acid obtained is $18.3 \%$-mol using $\mathrm{Ca}(\mathrm{OH})_{2}$ and $15.7 \%$-mol using $\mathrm{Mg}(\mathrm{OH})_{2}$ [22].

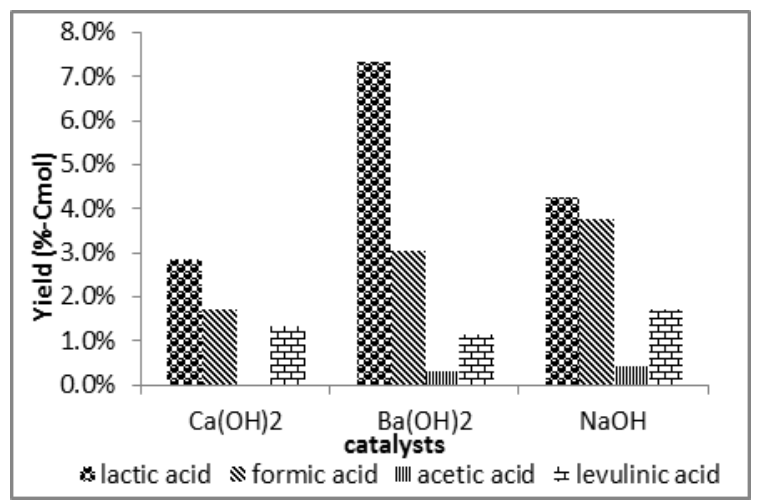

Fig. 1. The yield of lactic acid with alkaline catalyst at temperature of $200^{\circ} \mathrm{C}, 5 \% \mathrm{w} / \mathrm{v}$ biomass, and catalyst concentration $0.1 \mathrm{M}$

The temperature variations of $160^{\circ} \mathrm{C}, 200^{\circ} \mathrm{C}$, $240^{\circ} \mathrm{C}$ were carried out to examine the effect of temperature on catalytic conversion of EFB into lactic acid. The increased yield of lactic acid occurs because the increase of temperature. It was due to the increased activity of $\mathrm{Ba}^{2+}$ and the production rate of lactic acid also increases. The effect of temperature on the yield of lactic acid was also found in the previous research [23] with the raw material of glucose using $\mathrm{Ba}(\mathrm{OH})_{2}$, and research carried out by Wang et al., 2013 with the raw material of glucose and fructose using $\mathrm{Pb}^{2+} 2 \mathrm{mM}$. The concentration of lactic acid increased at the temperature of $170-230^{\circ} \mathrm{C}$.

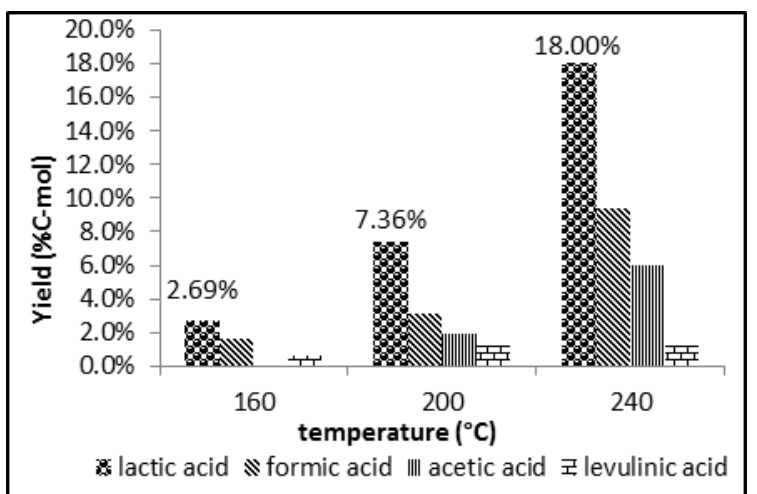


Fig. 2. The yield of lactic acid with variation of temperature, using $\mathrm{Ba}(\mathrm{OH})_{2} 0.1 \mathrm{M}, 5 \% \mathrm{w} / \mathrm{v}$ biomass

The yield of levulinic acid and formic acid as a byproduct were lower than acetic acid. Formic acid and levulinic acid were formed from 5-HMF. 5-Hydroxy methyl furfural (HMF) can be formed through the dehydration process of $\mathrm{C}_{6} \mathrm{H}_{12} \mathrm{O}_{6}$ by eliminating three molecules of $\mathrm{H}_{2} \mathrm{O}$. Formation of levulinic acid and formic acid occurs through HMF rehydration and not directly from sugar. Meanwhile the formation of other by-products of acetic acid occurs through the process of oxidation of levulinic acid [9], [24]-[26]. Beside pretreatment EFB, microcrystalline cellulose, another raw material was also used in this experiment. Figure 3 represents the yield of lactic acid using microcrystalline

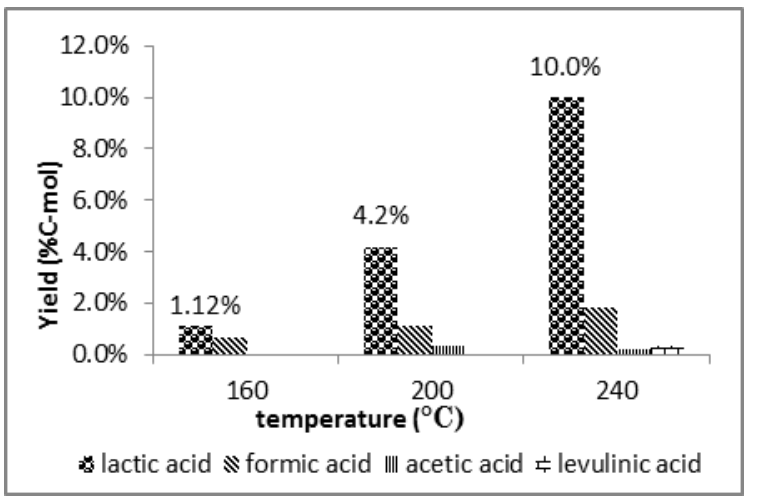

Fig. 3. The yield of lactic acid with variation of temperature, using $\mathrm{Ba}(\mathrm{OH})_{2} 0.1 \mathrm{M}, 5 \% \mathrm{w} / \mathrm{v}$ microcrystalline cellulose

as the raw material. The highest yield of lactic acid $10 \%$ C-mol, was achieved at a temperature of $240^{\circ} \mathrm{C}$. Yield of lactic acid from microcrystalline cellulose was lower than yield of lactic acid from EFB, although EFB has more complex structure than cellulose. The lower lactic acid yield was due to its crystalline structure on cellulose that caused cellulose hardly to be hydrolyzed to form sugar component compared with amorphous structure on steam explosion EFB [21]. The comparison between crystalline and amorphous structure in the production of lactic acid was also shown in research conducted by Chin et al. 2016. The yield of lactic acid using EFB untreated and ball mill EFB were 24.8\% mol and 42.5\% mol, respectively. Wang et al. 2013 showed that longer reaction time was needed to produced lactic acid in similar yield $(\sim 60 \%)$ when used microcrystalline cellulose $(15 \mathrm{~h})$ rather than ball mill cellulose $(4 \mathrm{~h})$.

The variation of reaction time was carried out to found the optimal reaction time on the production of lactic acid. This experiment was conducted at temperature of $240^{\circ} \mathrm{C}$ using $0.1 \mathrm{M} \mathrm{Ba}(\mathrm{OH})_{2}$ and $5 \% \mathrm{w} / \mathrm{v}$ biomass.

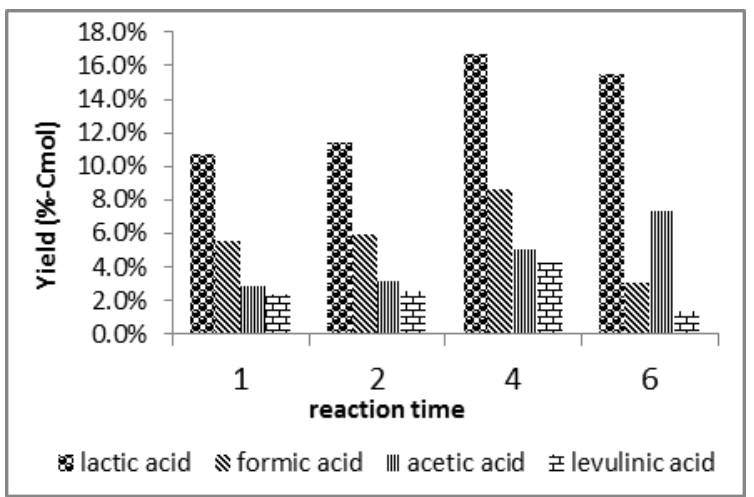

Fig. 4. The yield of lactic acid with variation of reaction time, using $\mathrm{Ba}(\mathrm{OH})_{2} 0.1 \mathrm{M}, 5 \% \mathrm{w} / \mathrm{v}$ biomass, temperature of $240^{\circ} \mathrm{C}$

The highest yield of lactic acid $(16.77 \% \mathrm{C}$-mol) was achieved at $4 \mathrm{~h}$ reaction time. The addition of reaction time to $6 \mathrm{~h}$ did not show an increase in yield of lactic acid. It was indicated that degradation of lactic acid occurred into other products. The oxidation process was predicted to occur during the reaction, which is also indicated by the increase of a concentration of acetic acid, and formic acid inasmuch as the increase of reaction time [27]. The highest acetic acid yield $(7.40 \%$ $\mathrm{C}$-mol) was obtained at $6 \mathrm{~h}$ reaction time. This phenomenon was in accordance with research conducted by Chin et al. (2016) in the formation of lactic acid from EFB using $\mathrm{Pb}^{2+}$.

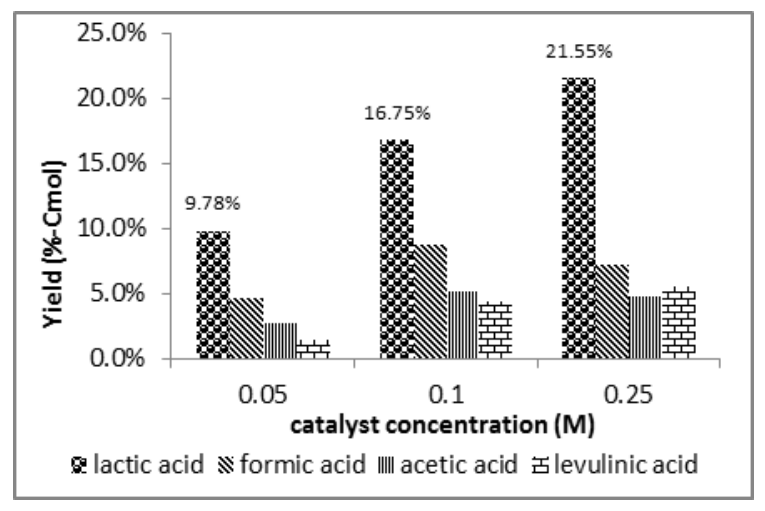

Fig. 5. The yield of lactic acid with variation of $\mathrm{Ba}(\mathrm{OH})_{2}$ catalyst concentration, $5 \% \mathrm{w} / \mathrm{v}$ biomass, temperature of $240^{\circ} \mathrm{C}$

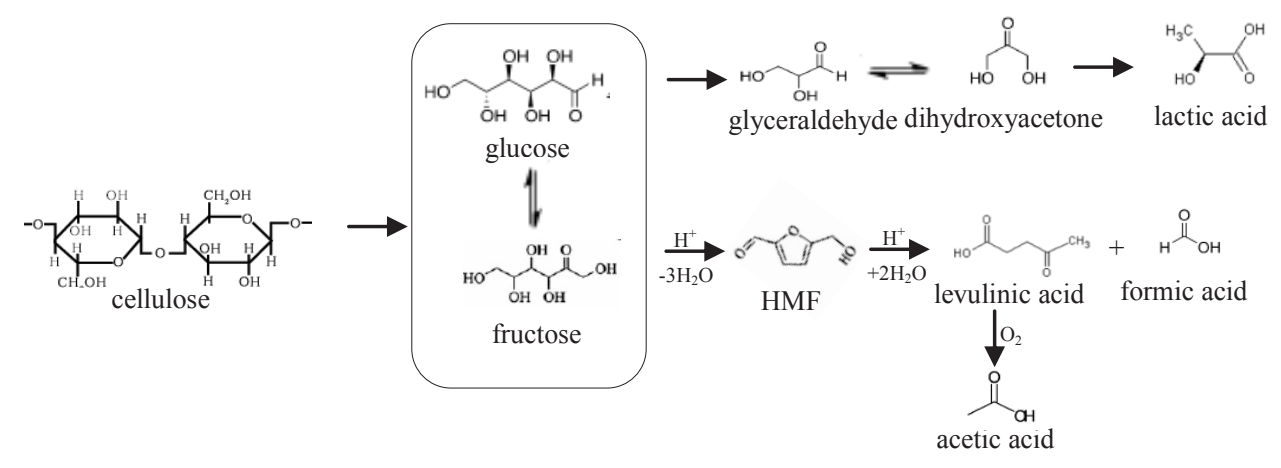


Fig. 6. Possible reaction pathway from the conversion of cellulose to lactic acid and by products

The variations of catalyst concentration on lactic acid production were shown in Figure 5. The highest lactic acid yield in this experiment was $21.57 \% \mathrm{C}$-mol, with catalyst concentration $0.25 \mathrm{M}$. The research concerning the conversion of glucose to lactic acid conducted by Esposito and Antonietti (2013) using $\mathrm{Ba}(\mathrm{OH})_{2}$ also showed the same phenomena. The yield of lactic acid using $0.1 \mathrm{M} \mathrm{Ba}(\mathrm{OH})_{2}$ was higher $(57 \% \mathrm{~mol})$ rather than $0.05 \mathrm{M}$ catalyst $(43 \% \mathrm{~mol})$. The same phenomena were obtained by Shen et al. (2009) on the production of lactic acid from glycerine using various alkaline catalysts with concentration $0.025-3 \mathrm{M}$. The increased of the yield of lactic acid was inasmuch as the concentration of the alkaline catalyst. The highest lactic acid achieved in that research was $90 \%$ mol using $\mathrm{KOH}$ as a catalyst, with concentration of $1.25 \mathrm{M}$. However, when the catalyst concentration was higher than $1.25 \mathrm{M}$, there was no significant effect on the yield of lactic acid obtained [22].

Increasing in the amount of biomass has caused decreasing in the yield of lactic acid, because the effectiveness of stirrer and catalyst performance during the reaction were also decreased. It can cause the formation of humin through dehydration of carbohydrate intermediates [9], [11], [28], [29]. The highest yield of lactic acid (19.32\% C-mol) was obtained with a biomass concentration of $2.5 \% \mathrm{~m} / \mathrm{v}$.

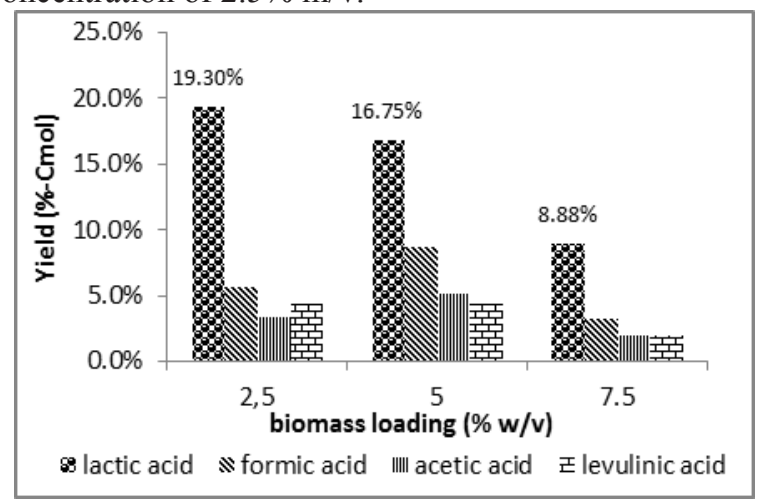

Fig. 7. The yield of lactic acid with variation of reaction time, using $\mathrm{Ba}(\mathrm{OH})_{2} 0.1 \mathrm{M}, 5 \% \mathrm{w} / \mathrm{v}$ biomass, temperature of $240^{\circ} \mathrm{C}$

Table 3.The production of lactic acid using various biomasses and catalysts

\begin{tabular}{|c|c|c|c|c|c|c|c|c|c|c|}
\hline \multicolumn{2}{|c|}{ Raw materials } & \multirow[b]{2}{*}{ Catalyst } & \multirow{2}{*}{$\begin{array}{c}\text { Catalyst } \\
\text { Concentration }\end{array}$} & \multirow{2}{*}{$\begin{array}{c}\text { Temperature } \\
\left({ }^{\circ} \mathrm{C}\right)\end{array}$} & \multirow{2}{*}{$\begin{array}{c}\text { Yield of } \\
\text { Lactic } \\
\text { Acid } \\
(\% \mathrm{C}-\mathrm{mol})\end{array}$} & \multicolumn{5}{|c|}{ Yield of byproduct (\% C-mol) } \\
\hline Biomass & $(\% \mathrm{~m} / \mathrm{v})$ & & & & & $\begin{array}{c}\text { formic } \\
\text { acid }\end{array}$ & $\begin{array}{l}\text { acetic } \\
\text { acid }\end{array}$ & $\begin{array}{l}\text { levulinic } \\
\text { acid }\end{array}$ & $\mathrm{HMF}$ & Furfural \\
\hline $\begin{array}{l}\mathrm{a}^{*} \text { Steam } \\
\text { Explosion } \\
\text { EFB }\end{array}$ & 5 & $\mathrm{Ba}(\mathrm{OH})_{2}$ & $0.1 \mathrm{M}$ & 240 & 21.57 & 7.16 & 14.7 & 6.6 & \multicolumn{2}{|c|}{ NA } \\
\hline $\begin{array}{l}\mathrm{a}^{*} \text { Steam } \\
\text { Explosion } \\
\text { EFB }\end{array}$ & 5 & $\mathrm{PbCl}_{2}$ & $0.1 \mathrm{M}$ & 240 & 23.67 & 1.5 & 4.94 & 1.033 & \multicolumn{2}{|c|}{ NA } \\
\hline${ }^{b *} \mathrm{EFB}$ & 2.5 & $\mathrm{AlCl}_{3}$ & $0.1 \mathrm{M}$ & 230 & 13.38 & \multicolumn{5}{|c|}{ NA } \\
\hline $\begin{array}{l}{ }^{c^{*} \text { Ball mill }} \\
\text { EFB }\end{array}$ & 0.5 & $\mathrm{PbCl}_{2}$ & $2 \mathrm{mM}$ & 210 & 21.25 & - & $\mathrm{v}$ & - & - & - \\
\hline $\mathrm{d}^{*}$ Cellulose & 5 & $\mathrm{PbCl}_{2}$ & $0.05 \mathrm{M}$ & 220 & 23.10 & - & - & - & \multicolumn{2}{|c|}{ NA } \\
\hline
\end{tabular}

$\mathrm{a}^{*}$ This experiment. Reaction time $4 \mathrm{~h}$.

b* Sitompul et. al, (2014). Reaction time 3h, EFB without pretreatment.

$c^{*}$ Chin et. al, (2016). Reaction time $2 \mathrm{~h}$, EFB with ballmill treatment.

$\mathrm{d}^{*}$ Alisyahbana and Asrizal (2014). Catalyst concentration $0.05 \mathrm{M}$, reaction time 4h.

The results of this experiment were also in accordance with previous research conducted by Li (2014) on the production of lactic acid using alkaline catalysts with raw materials of glucose, fructose, mannose, and xylose. The research showed that the increasing of fructose concentration from $1 \mathrm{~g} / \mathrm{L}$ to $8 \mathrm{~g} / \mathrm{L}$, the yield of lactic acid decreased from $70 \% \mathrm{C}$-mol to $57 \% \mathrm{C}$-mol.

Further, table 3 showed the yield of lactic acid using alkaline and other lewis acid catalysts from the conversion of EFB. Lactic acid produced from EFB using $\mathrm{PbCl}_{2}$ of $21.25 \% \mathrm{C}$-mol is the highest yield compared to other catalysts with $2 \mathrm{~h}$ reaction time [21]. Differences in reaction temperature, percentage of the amount of raw material and the treated or untreated EFB can affect the yield of lactic acid. However, considering the toxicity of $\mathrm{Pb}^{2+}, \mathrm{Ba}(\mathrm{OH})_{2}$ as the alkaline catalyst can be one of the best options. Further research with the larger scope of operating conditions needs to be carried out so it can be compared accurately.

\section{Conclusion}

The EFB pretreatment with steam explosion could reduce $57.24 \% \mathrm{w} / \mathrm{w}$ lignin content, increase $53.79 \% \mathrm{w} / \mathrm{w}$ cellulose, and $16.95 \% \mathrm{w} / \mathrm{w}$ hemicellulose. The highest yield of lactic acid $21.57 \% \mathrm{C}$-mol was achieved using $0.25 \mathrm{M} \mathrm{Ba}(\mathrm{OH})_{2}, 5 \% \mathrm{~m} / \mathrm{v}$ biomass, and temperature of $240^{\circ} \mathrm{C}$, during $4 \mathrm{~h}$ reaction time. Production of lactic acid with $\mathrm{Ba}(\mathrm{OH})_{2}$ and $\mathrm{Pb}^{2+}$ as catalyst gave 
approximately equal yield of lactic acid $(\sim 20 \%)$. The use of $\mathrm{Pb}^{2+}$ catalysts for the production of lactic acid is more advantageous because it produces fewer by products. $\mathrm{Ba}(\mathrm{OH})_{2}$ could be a good choice for the development of versatile products from EFB.

\section{Acknoledgement}

This research is funded by Indonesia Estate Crop Fund for Palm Oil through the Ministry of Finance and Research Incentive Program : The National Innovation System through the Ministry of Research and Technology. Dr. H.W. Lee was supported by the National Research Foundation of Korea (NRF Korea) through the TPC program for this work.

\section{References}

1. A. Wijono, Simp. Nas. III, (2014)

2. N. Abdullah, F. Sulaiman, J. Phys. Sci 2, 2 (2013)

3. A.S. Baharuddin, A. Sulaiman, D.H. Kim, M.N. Mokhtar, M.A. Hassan, M. Wakisaka, Y. Shirai, H. Nishida, Biomass Bioenergy 55, (2013)

4. Y. Sudiyani, D. Styarini, E. Triwahyuni, Sudiyarmanto, K.C. Sembiring, Y. Aristiawan, H. Abimanyu, M.H. Han, Energy Procedia 32, (2013)

5. S.A.M. Saman, Y. Uemura, S. Yusup, Procedia Chem 9, (2014)

6. G. V. Research, Market research and consulting, (2014)

7. M. Bicker, S. Endres, L. Ott, H. Vogel, J. Mol. Catal. A: Chem 239, 1-2 (2005)

8. A. Onda, T. Ochi, K. Kajiyoshi, K. Yanagisawa, Appl. Catal., A 343, 1-2 (2008)

9. C.B. Rasrendra, B.A. Fachri, I.G.B.N. Makertihartha, S. Adisasmito, H.J. Heeres, ChemSusChem 4, 6 (2011)

10. Z. Tang, W. Deng, Y. Wang, E. Zhu, X. Wan, Q. Zhang, Y. Wang, ChemSusChem 7, 6 (2014)

11. Y. Wang, W. Deng, B. Wang, Q. Zhang, X. Wan, Z. Tang, Y. Wang, C. Zhu, Z. Cao, G. Wang, H. Wan, Nat. Commun 4, (2013)

12. J.P. Sitompul, R.F. Simangunsong, A.A. Asrizal, H. Alisyahbana, H.W. Lee, C.B. Rasrendra, Procedia Chem 9, (2014)

13. R. P. John, A. G.S., K. M. Nampoothiri, A. Pandey, Biotechnol. Adv 27, 2 (2009)

14. E. Taarning, S. Saravanamurugan, M.S. Holm, J. Xiong, R.M. West, C.H. Christensen, ChemSusChem 2, 7 (2009)

15. F.F. Wang, C.L. Liu, W.S. Dong, Green Chem 15, 8 (2013)

16. P. Alvira, E.T. Pejo, M. Ballesteros, M.J. Negro, Bioresour. Technol 101, 13 (2010)

17. Y. Sun, J. Cheng. Bioresour. Technol 83, 1 (2002)

18. P. Harmsen, W. Huijgen, L.M.B. Lopez, R.R.C. Bakker, ECN (2010)

19. P. Kumar, D.M. Barrett, M.J. Delwiche, P. Stroeve, Ind. Eng. Chem. Res 48, 3713-3729 (2009)

20. P. Bajpai, Green Chem Sustain 34, (2016)

21. S. X. Chin, S. M. Tasirin, H. Chan, H. Chia, BioResources 11, 1 (2016)
22. Z. Shen, F. Jin, Y. Zhang, B. Wu, A. Kishita, K. Tohji, H. Kishida, J. Ind. Eng. Chem. Res 2, (2009)

23. D. Esposito, M. Antonietti, ChemSusChem 6, 6 (2013)

24. F. Jin, J. Yun, G. Li, A. Kishita, H. Enomoto, Green Chem. 10, (2008)

25. R. Van Putten, J. C. Van Der Waal, E. De Jong, C.B. Rasrendra, H.J. Heeres, J.G. De Vries, Chem. Rev 113, (2013)

26. Y. Wang, G. Yao, F. Jin, Green Chem. Sustain. Technol (2014)

27. L. Yang, J. Su, S. Carl, J.G. Lynam, X. Yang, H. Lin, Appl. Catal. B 162, (2015)

28. H. Alisyahbana, A.A. Asrizal, Institut Teknologi Bandung (2014)

29. M. Li, Auburn University (2014) 